\title{
6 Reforming the public sector: personalised activation services in the UK
}

Bruce Stafford and Karen Kellard

\section{Abstract}

This paper highlights the degree of flexibility and personalisation in the UK's welfare to work programmes. The Labour Government's New Deals as originally designed were meant to provide personalised and tailor-made services and to meet the needs of individuals. The programmes have evolved and become more personalised and promote flexible service delivery. The chapter explores the Personal Adviser model and focuses on the development of New Deal for Young People and New Deal 25 Plus. In recent years a number of factors appear to have encouraged the development of more personalised activation services in the UK. 


\section{Introduction}

The Labour Government since its election in 1997 has sought to tackle poverty and social exclusion in the UK and ensure that Britain is competitive in the global economy by virtue of a skilled and flexible labour force. It has introduced a number of policies, including active labour market programmes, which promote work as the best means of reducing poverty and social exclusion. The design of these programmes has changed over time, and this chapter discusses the degree to which the delivery of welfare and employment services is being made more personalised. ${ }^{1}$ These trends will be illustrated by the two largest activation programmes in the U.K.: the New Deal for Young People and the New Deal 25 Plus. Both these programmes are aimed at the unemployed, that is, recipients of Jobseeker's Allowance. However, as there are New Deals aimed at other client groups - for instance, lone parents - the chapter also touches on the experiences of recipients of other benefits. The chapter begins by placing these developments in their policy and economic context.

\section{Policy and economic context}

The key policy and economic factors that have influenced the development of active labour market policies are the Labour Government's employment policy, levels of employment and unemployment in the UK, the main characteristics of unemployed people, the Government's proposed reforms of the public sector and its reform of welfare to work policies. 


\section{Employment policy}

Tackling unemployment is central to the Government's long-term objectives of economic growth and rising living standards. The aim of the Government's employment policy is "... to ensure a higher proportion of people in work than ever before" (HM Treasury, 2005, para 1.7). The Department for Work and Pensions, which has responsibility for employment and benefit policies, has targets agreed with the Treasury for the period 2005-06 to 2007-08 to: increase overall employment rates over the economic cycle; increase the employment rates of disadvantaged areas and groups (such as disabled people), taking account of the economic cycle; and reduce the number of children in workless households (DWP, 2005).

Associated with this has been a desire to secure a cultural shift in the contract between the individual and the State (Blunkett, 2000). Within a policy agenda that emphasises rights and responsibilities, the Government has sought to convert what it saw as a passive system to an active one, whereby the right of individuals to get support from the Government when looking for work is balanced by the responsibility to seek training and work if able to do so. The one set of policies that stand out as active labour market policies are the New Deals, which are central to New Labour's Welfare to Work strategy and its modernisation of the welfare state.

\section{Employment and unemployment in the UK}

In recent years, the U.K. labour market has been relatively robust and unemployment 
has been maintained at comparatively low levels. Although the rate of employment does vary by the business cycle, at the end September 2005 there were 28.80 million people in employment, the highest since records began in 1971 (NS, 2005). Since 1959 the rate of employment has varied between 70 and 75 per cent, and at September 2005 was 74.9 per cent. Unemployment in the UK rose following the 'oil crisis' of the 1970 s and the recessions of the 1980 s and early 1990s. Since 1993 the trend has been downwards. As at September 2005 the unemployment rate, using the ILO definition, ${ }^{2}$ was 4.7 per cent, with 1.43 million people unemployed. According to the Government the strong performance of the labour market has been achieved through working towards five main principles (HM Treasury/DWP, 2003):

- Macroeconomic stability;

- Flexibility in the labour market, within a regulated framework;

- Tax and benefit policies that make work pay;

- Ensuring an adaptable, flexible and productive workforce through training and education; and

- Activation policies that aim to prevent people becoming detached from the labour market.

As unemployment levels have fallen attention has focused more on those unemployed people who are harder to reach and on the, now larger, population of benefit recipients who are economically inactive. Differences in the composition of the workless population, such as having a disability, and of the wider economically inactive population, have affected the design of labour market programmes such as the New 
Deals. Different New Deals have been developed for distinct client groups; for example, young people and disabled people (see Stafford, 2003a). These programmes reflect differences in both key characteristics of the target groups and benefit status (with mandatory programmes for those claiming Jobseeker's Allowance as they have to be actively seeking work as a condition of benefit entitlement, and voluntary programmes for groups in receipt of other benefits, such as Income Support (lone parents) and Incapacity Benefit (people with a disability or health condition)).

\section{Public sector reform}

In recent years, the Labour Government has placed a renewed emphasis on the delivery of public services. For political reasons the reform of public services has been given predominance by Ministers, including the Prime Minister. Central to the political and policy debate is the concept of choice - of allowing individuals to choose a service from different providers - and that services must be responsive or customer-focused. Choice is believed to drive up standards and empower customers. Introducing marketled approaches to the public sector is not new in the UK, initiatives such as competitive tendering of services and internal markets date back to the 1980s and 1990s. However, the current emphasis on customer-focused public services is a step change in policy development. It is under Labour that the notion of the demanding 'citizen customer' has gained ascendancy.

The 1999 White Paper, Modernising Government, included a commitment to provide responsive public services (HC, 1999). The aim was that service users, not providers, 
would be the focus of public services, so that customers' needs are met. A raft of measures to modernise government were announced, many were existing initiatives, such as the planned establishment of a one stop shop for benefit claimants of working age, Jobcentre Plus. ${ }^{3}$ In a speech on modernising the Civil Service, Tony Blair declared:

"Consumer expectations of Government services as well as others are rising remorselessly. People no longer take what is given them and are grateful. They want services that are responsive to their needs and wishes."

(Blair, 2004)

The Government's reform agenda is controversial both within and outside of Government. The nature of this debate is not outlined here, rather it is sufficient to note that there is a wider debate in the UK about individual and collective choice and about the extent to which the provision of public services should be personalised.

\section{Welfare reform}

In general, the debates about public sector reform, and about choice in particular, centre on education and the health service. However, some of the ideas now given more national prominence underscore both earlier and current reforms of the welfare state. The 1998 consultation paper, New Ambitions for our Country: A new contract for welfare (HC, 1998a) outlined the Government's principles and 'vision' for reform. The 
Green Paper outlined the case for "developing flexible personalised services to help people into work". In part this reflects Ministers' criticisms of the way in which benefits had been delivered, speaking in 1997 the then Secretary of State commented:

"The way that social security is delivered at the moment is resented by the public who pay for it, the clients who use it, and the staff who run it. For many people, the current system is fragmented, reactive, inflexible and confusing. ... I am determined to overhaul the service that we have inherited I want to develop a modern integrated system that is simpler, streamlined and more efficient."

(Secretary of State, 1997)

The service was seen as not keeping "pace with rising expectations of service quality". Indeed, one Minister described it as a "second class service"; claiming it does not meet individuals' needs (Eagle, 1999). Instead, customers ought to have:

"... the right to good quality, convenient and responsive services which both help them with their individual needs and enable them to fulfil the obligations which go with receiving benefits."

(HC, 1998a, ch 10, para 1)

Indeed, independent research supports Ministers' critical comments of the 'traditional' method of delivering benefit and employment services (for a summary see Stafford, 2003b). 
The Green Paper sought to extent the then Personal Adviser service available to lone parents under the New Deal for Lone Parents and to young people under the New Deal for Young People to other client groups of working age. The aim was to provide a tailor-made, personalised service that would be summarised in an Action Plan for each customer. Personal Advisers were to meet with customers and to discuss work aspirations and options, to assist with job-search, to explore training needs and provision, to produce indicative calculations of whether a customer will be better off in work and to advise (as appropriate) on childcare provision and the availability of specialist referral services (for example, to deal with drug or alcohol abuse).

Whilst a caseworker approach with lone parents had been piloted by the Conservatives (Vincent et al., 1998), Labour developed and extended the concept to other client groups. Indeed, the Personal Adviser model is not only inherent in the design of the New Deals (see below), but also a feature of the 'work-focused interviews' conducted in Jobcentre Plus offices. On the 1 April 2002 the Employment Service and parts of the Benefits Agency were merged to form Jobcentre Plus, which delivers employment and benefit services to people of working age. Jobcentre Plus provides services to unemployed people claiming the UK's unemployment benefit, Jobseeker's Allowance, and to other people claiming social assistance and incapacity benefits. The national rollout of this new service will be completed in 2006. This new organisational structure is complemented by the introduction of mandatory work-focused interviews for all new claims, including those made by the unemployed, lone parents, sick and disabled 
people and widows. These involve Personal Advisers and customers discussing the latter's work aspirations, and their barriers to and opportunities for employment. Whilst, formally, there is no requirement to seek work or be available for work for nonJobseeker's Allowance claimants, there is increasingly a focus on getting people, whether or not they are unemployed, into employment.

\section{The new deals}

There is a 'family' of New Deal programmes (see Table 1) that differ in terms of the client group targeted, whether participation is mandatory and the nature of the intervention. They are 'labourist' activation policies, because they assume social inclusion is achieved through labour market engagement and employment. There is a New Deals policy paradigm with:

- a focus on paid work as the 'the single most effective' or 'surest route out of poverty' and social exclusion and the best means for securing independence (HC, 1998a; HM Treasury, 2000a and 2002b);

- a belief that welfare to work policies are necessary to prevent the unemployed and economically inactive becoming detached from the labour market (HM Treasury, 2002a);

- an expectation that increasing the supply of labour will increase the pool of (skilled) labour available to employers, which will increase production and productivity (Blunkett, 2000; HM Treasury, 2000a);

- a belief that movements into work can be assisted by:

$>$ delivering a proactive benefit system founded on a flexible, integrated, 
personalised (or caseworker) service backed by investment in information and communication technology (HC, 1998b);

providing enabling services and support that tackle people's barriers to work and improve their employability;

- a stress on the rights and responsibilities of individuals and of the State (HC, 1998a); and

- a willingness to work in partnership with the voluntary and private sectors in delivering benefit and employment services.

The New Deals are very much a supply-side policy. There is an aspect of the 'democratisation of activation' in the New Deals (c.f. the chapter by Johansson) in that they extent the range of clients groups to be covered from the unemployed (Jobseeker's Allowance recipients) to lone parents and disabled people claiming other benefits. 
Table 1 Summary of New Deal Programmes

\begin{tabular}{|c|c|c|c|c|}
\hline New Deal & Participation & Commenced & Target Group & Content \\
\hline $\begin{array}{l}\text { New Deal } \\
\text { for Lone } \\
\text { Parents }\end{array}$ & Voluntary & $\begin{array}{l}\text { Prototypes: } \\
\text { October } 1997 \\
\text { National: } \\
\text { October } 1998\end{array}$ & $\begin{array}{l}\text { (From 2001) Lone } \\
\text { parents on Income } \\
\text { Support who work less } \\
\text { than } 16 \text { hours a week or } \\
\text { not at all, and their } \\
\text { youngest child aged } \\
\text { under } 16 \text { years }\end{array}$ & $\begin{array}{l}\text { Consists of an initial interview with a Personal } \\
\text { Adviser, a review meeting after six and } 12 \text { months } \\
\text { and annual meetings subsequently (if they remain on } \\
\text { Income Support). The Personal Adviser discusses } \\
\text { work options and provides support whilst looking for } \\
\text { work and once in work. }\end{array}$ \\
\hline $\begin{array}{l}\text { New Deal } \\
\text { for Young } \\
\text { People }\end{array}$ & Mandatory & $\begin{array}{l}\text { Pathfinders: } \\
\text { January } 1998 \\
\text { National: } \\
\text { April } 1998\end{array}$ & $\begin{array}{l}\text { Individuals aged } 18 \text { to } \\
24 \text { and claiming } \\
\text { Jobseeker's Allowance } \\
\text { for at least six months }\end{array}$ & $\begin{array}{l}\text { Includes a 'gateway' period of advice and support } \\
\text { followed by one of four options (subsidised } \\
\text { employment, full-time education and training, } \\
\text { voluntary work, environmental work). From April } \\
2004 \text {, a 'flexible' Options stage will be introduced: } \\
\text { customers can 'mix and match' Options and the } \\
\text { minimum required length of stay on all Options is } \\
\text { reduced from } 26 \text { to } 13 \text { weeks. There is a review of } \\
\text { progress at week } 10 \text { of the Option period. }\end{array}$ \\
\hline $\begin{array}{l}\text { New Deal } \\
25 \text { plus }\end{array}$ & Mandatory & $\begin{array}{l}\text { National: } \\
\text { June } 1998 \\
\text { Pilots: } \\
\text { November } \\
1998^{1}\end{array}$ & $\begin{array}{l}\text { Jobseeker's Allowance } \\
\text { claimants for } 18 \text { out of } \\
\text { the last } 21 \text { months }\end{array}$ & $\begin{array}{l}\text { Personal Advisers offer } 13 \text { week Intensive Activity } \\
\text { Period which can be extended to } 26 \text { weeks at } \\
\text { Adviser's discretion, or to } 52 \text { weeks for full-time } \\
\text { education or training. }\end{array}$ \\
\hline $\begin{array}{l}\text { New Deal } \\
50 \text { Plus }\end{array}$ & Voluntary & $\begin{array}{l}\text { Pathfinders: } \\
\text { October } 1999 \\
\text { National: } \\
\text { April } 2000\end{array}$ & $\begin{array}{l}\text { Claimants of work } \\
\text { related benefits aged } \\
\text { over } 50\end{array}$ & $\begin{array}{l}\text { Personal Advisers provide support for job search, } \\
\text { work, financial advice regarding transition into work, } \\
\text { and an 'in-work' training grant. }\end{array}$ \\
\hline
\end{tabular}




\begin{tabular}{|c|c|c|c|c|}
\hline New Deal & Participation & Commenced & Target Group & Content \\
\hline $\begin{array}{l}\text { New Deal for } \\
\text { Partners }\end{array}$ & Voluntary & $\begin{array}{l}\text { Pathfinder: } \\
\text { February } 1999 \\
\text { National: } \\
\text { April } 2000\end{array}$ & $\begin{array}{l}\text { Partners of recipients of } \\
\text { Jobseeker's Allowance, } \\
\text { Income Support, } \\
\text { Incapacity Benefit, } \\
\text { Severe Disablement } \\
\text { Allowance and Carer's } \\
\text { Allowance }\end{array}$ & $\begin{array}{l}\text { Those aged } 18 \text { to } 24 \text { and without children can } \\
\text { choose to join the NDYP. For parents aged } 18 \text { to } \\
24 \text { and those aged } 25 \text { plus, there is access to a } \\
\text { Personal Adviser to provide information regarding } \\
\text { help and support available to find work, including } \\
\text { financial incentives and childcare. }\end{array}$ \\
\hline $\begin{array}{l}\text { New Deal for } \\
\text { Disabled } \\
\text { People }\end{array}$ & Voluntary & $\begin{array}{l}\text { Pilots: } \\
\text { October } 1998 \\
\text { National: } \\
\text { July } 2001\end{array}$ & $\begin{array}{l}\text { Those receiving } \\
\text { disability or health- } \\
\text { related benefits }\end{array}$ & $\begin{array}{l}\text { A network of Job Brokers provide advice and } \\
\text { support to find and prepare for work. Job Brokers } \\
\text { are paid on their outcomes - registering } \\
\text { participants, job entries and sustained } \\
\text { employment. }\end{array}$ \\
\hline $\begin{array}{l}\text { New Deal for } \\
\text { Musicians }\end{array}$ & Voluntary & $\begin{array}{l}\text { Pathfinder: } \\
\text { October } 1999 \\
\text { National: } \\
\text { Spring } 2000\end{array}$ & $\begin{array}{l}\text { Those already on New } \\
\text { Deal for Young People } \\
\text { or New Deal } 25 \text { Plus }\end{array}$ & $\begin{array}{l}\text { If in these New Deal programmes, individual can } \\
\text { demonstrate genuine interest in working as a } \\
\text { musician, Personal Advisers will make referral to } \\
\text { music industry expert to be mentor and provide } \\
\text { support and advice. }\end{array}$ \\
\hline
\end{tabular}

${ }^{1}$ Innovative schemes were piloted in selected areas after the programme had been introduced in 28 areas.
Taken from: Hasluck, (2000), Table A.1, p. 71; Millar, (2000), Table 2.1. Updated from www.newdeal.gov.uk 


\section{The Personal Adviser model}

In general, customers and staff like the Personal Adviser model. In the New Deal for Young People, for instance, claimants like the one-to-one contacts they have with their Adviser (Bryson et al., 2000) and tend to be satisfied with their Personal Advisers (Bonjour et al., 2001). Six months after programme entry 91 per cent of respondents in a survey said they got along very well or quite well with their Personal Advisers (Bryson et al., 2000). However, the quality of the relationship varied by programme Option (see Table 1). Those attending Options that were closer to the labour market (the Employment Option (60 per cent)) were more likely to get on very well with their Personal Advisers than those on options further from the labour market (the Environmental Task Force (47 per cent)) (Bonjour et al., 2001).

Notwithstanding evidence that claimants and staff have had positive views about the Personal Adviser model (see, for instance, Legard et al., 1998; Arthur et al., 1999; Atkinson, 1999; Finch et al., 1999; Legard and Ritchie, 1999; Woodfield et al., 1999; Lewis et al., 2000; Kelleher et al., 2002; Osgood et al., 2002), there are (inevitably) some shortcomings in the Personal Adviser model, and some claimants have mixed views about the service received.

The extent to which claimants' needs and barriers to work are identified can vary between Advisers. Some adopt a 'holistic' approach that explores the broader social and economic needs of individuals, whilst 
others are more narrowly focused on work-related issues (Lewis et al., 2000). Although claimants' demand for a more comprehensive service might vary, some customers do value the interest shown in them as individuals by some Personal Advisers (Finch et al., 1999; Legard and Ritchie, 1999; Lewis et al., 2000). However, Personal Advisers typically provide a service that is more narrowly focused on work-outcomes for unemployed people (that is, those claiming Jobseeker's Allowance), whereas those claiming other benefits, especially those with complex needs, often received a limited service (Kelleher et al., 2002). Frequently, there was a focus on sorting out the benefit claim and not on work aspirations or barriers to participation in the labour market.

Moreover, despite the emphasis on employment in the Government's welfare reforms, an evaluation of a pilot version of Jobcentre Plus showed that the delivery of work-focused interviews can be problematic (Kelleher et al., 2002; Osgood et al., 2002). Time pressures meant that early meetings with claimants tended to concentrate on their claim for benefit, and work-related issues were generally neglected.

In principle, Personal Advisers are encouraged to caseload claimants to appropriate services or support. However, there is some qualitative evidence of Personal Advisers 'creaming' the most job ready claimants (Arthur et al., 1999; Loumidis et al., 2001; Kelleher et al., 2002) (see also discussion of employability by Bonvin and Farvaque in this volume). This is partly a response to a lack of resources, an unintended consequence of 
increasing numbers of claimants and limited staff making the scheduling of follow-up meetings problematic, in particular for customers with complex or long term employment issues. It is also partly because Personal Advisers can lack the skills and experience to deal with claimants with particularly complex or sensitive personal circumstances and job placement targets encourage staff to focus on those most job ready. To cope with this situation, more difficult cases can be referred to internal or external specialists (such as Lone Parent Advisers or Disability Employment Advisers), deselecting cases from the caseload and/or team working.

Finally, Personal Advisers have an advocacy role, of championing their customers' needs with, for instance, service providers and employers. However, Personal Advisers are 'gatekeepers' to resources and other services, and, if necessary, refer cases for decisions on benefit sanctions. Ultimately the relationship between Personal Advisers and claimants is not one of equals; the relationship is asymmetrical with the advisers in charge (c.f. Johansson this volume). There is a potential tension between these two roles that limits the rapport that Personal Advisers can establish with their customers.

\section{Other measures}

The New Deals operate within a wider policy climate of work incentives, tax and benefit changes and employment service initiatives and schemes aimed at specific disadvantaged client groups or geographical areas. Measures include reforming National Insurance (that is, social insurance) 
contributions and the introduction of tax credits for working families and for people with disabilities (in October 1999) and of a national minimum wage (in April 1999). As well as steps taken to improve pay for those on low incomes, other measures have been put in place to ease the transition into work. Work incentive measures such as Job Grant, Lone-Parent Benefit Run-on and Housing Benefit Run-on are designed to assist those who undergo the transition from benefit receipt into paid employment.

Targeted geographical initiatives include area regeneration schemes such as, New Deal for Communities and a 'family' of Action Zones for Health, Education and Employment. The New Deal for Communities, for example, was launched in September 1998 and is a key programme in the Government's strategy to help some of the most deprived neighbourhoods in the country. The programme aims to bridge the gap between some of the poorest members of society and the rest of Britain. By focusing resources on small deprived areas, and working with other initiatives operating in the areas, it seeks to achieve maximum impact.

\section{Making it more personal}

In summary, the Labour Government's welfare reforms have entailed from the very beginning a degree of personalised service delivery through the Personal Adviser model as typified in the New Deals. The model has also been adapted and will be the 'norm' as Jobcentre Plus is rolled-out nationally. Notwithstanding some criticisms of the Personal Adviser model 
(see above), there is evidence that it is becoming more personalised and the New Deals made more flexible. There are two main reasons for arguing this. First the evolution of, and the interactions between, the New Deal for Young People and New Deal 25 Plus are leading to more 'flexible' services, which by their nature are more tailored and so personalised. Secondly, there are several other policies and schemes aimed at the harder to reach, which in order to be effective have to be more personalised in their approach.

\section{Evolution of programme design - the New Deal for Young People and}

\section{New Deal 25 Plus}

New Deal for Young People is a mandatory programme for young people who have been claiming Jobseeker's Allowance for six months. As originally designed it entailed (Chatrik and Convery, 1999):

- A Gateway period of up to four months where a Personal Adviser (or staff from a specialist external agency) provides advice and support to help claimants' secure unsubsidised employment. Claimants are given help with job-search, careers advice and preparation for the next Options stage. Sanction for refusal to participate in the programme is a time-limited withdrawal of Jobseeker's Allowance. To make young people more prepared for work and to improve their job-search skills an Intensive Gateway (the 'Gateway to Work') was piloted in 12 areas in August 1999 and rolled out nationally in June 2000 (HM Treasury, 2000a). This offered more intensive help from Personal Advisers with job-search and assistance with developing individuals' soft skills 
including punctuality, team working etc. In addition, since July 1999 the last month of the Gateway has been made more intensive, so participants are made aware that remaining on benefits is not an option and prepares them for the next stage of the programme (Options). Nonetheless, some participants remain in the Gateway for longer than four months.

- After the Gateway employment and work experience Options for those still unemployed. The Options comprise: a subsidised job for up to six months or help starting their own business; work in the voluntary sector for up to six months; a job with the Environmental Task Force for up to six months; or full-time study for up to 12 months for people with no or only basic educational qualifications. There is an expectation, although no guarantee, that subsidised placements will lead to permanent positions. Each option involves at least one day per week (or equivalent) off-the-job training leading to an accredited qualification. This is a compulsory phase of the programme; and those refusing to participate may face benefit sanctions.

- A Follow Through phase of further intensive job-search for those not in unsubsidised employment.

Claimants who have not found a job or other opportunities at the end of these stages may return to claim Jobseeker's Allowance.

Evidence of the evolution of a more personalised programme is that the Government is changing the Options stage of the programme. The 
"Tailored Pathways" pilot was introduced in 17 Jobcentre Plus areas in 2002 , to test the impact of a more flexible approach to the Options stage of New Deal for Young People. The pilot enables New Deal Personal Advisers to put together a modular package of support that could include periods of training, work experience and subsidised employment. A flexible Option period was intended to better enable provision to be tailored to the needs of employers and individual young people. The pilot has recently been evaluated, and was found to produce small but significant increases in job outcomes in pilot areas (Griffiths et al., 2003). In the 2003 Budget the Chancellor announced that a more flexible Options period would be introduced. From April 2004, Personal Advisers will be able to 'mix and match' Options and define the length of stay of each customer. The minimum length of stay is also reduced from 26 to 13 weeks. (Although the full-time education and training option can still last for a maximum of 52 weeks in exceptional circumstances.) The customers' progress will be reviewed at week 10 at a Job Readiness Review. At the review the Personal Adviser will determine whether the customer's length of stay on New Deal for Young People will be extended, for a period of up to 13 weeks. At any point during the Options period a customer will be able to access the full 26 weeks of the Employment Option.

This more flexible, personalised version of New Deal for Young People is in part a response from the lessons learnt from the New Deal 25 Plus. The New Deal 25 Plus has undergone more radical change than the New 
Deal for Young People. Its evolution, which is outlined below, reveals the implementation of a more personalised (yet work-focused) service.

The target group for New Deal for 25 Plus has changed over time. Initially, Jobseekers (or those with National Insurance contributions) aged 25 and over and who had been unemployed for at least two years were eligible for the programme. However, in design and funding the programme was less developed than the New Deal for Young People. There was no Options stage, guaranteed training for the participant or training grant for employers. It also follows that the opportunity for subsidised employment was not a mandatory part of the programme. Overall, the programme's duration varied, depending upon customers' circumstances, and ranged from several months to a year.

This early version of the New Deal 25 Plus was a relatively modest programme; in effect it comprised additional sessions with a Personal Adviser and a re-packaging of existing programmes for the long-term unemployed (such as Jobclub, Work Trials and Access to Work). It was developed in haste by Ministers and compared unfavourably with the 'flagship' New Deal programme for 18-24 year olds. The relatively small size of the funding compared to the size of the client group meant that resources were spread thinly amongst participants and there would only be a modest number with subsidised jobs. The programme was in danger of appearing to offer more than it could in practise deliver. 
In practice, the early version of New Deal for 25 Plus lacked "pace and purpose" and the advisory period lasted too long (Hasluck, 2002). Most participants left the programme after the advisory stage and returned to Jobseeker's Allowance.

In November 1998 an enhanced version of New Deal 25 Plus was piloted in 28 areas in Great Britain and in the whole of Northern Ireland. In the pilots in Great Britain jobseekers became eligible for the New Deal 25 Plus at either 12 or 18 months of unemployment. A mix of public and private sector (partnership) organisations, including the then Employment Service, delivered the programme. The pilots were meant to be innovative and they tested a number of different measures and models of delivery. They also drew upon the New Deal for Young People, in particular they incorporated a Gateway. The pilots ran until March 2001.

In April 2000 the Gateway in New Deal 25 Plus was further intensified, with more contacts with clients and additional support provided. However, an evaluation assessed the overall impact of these changes to be marginal, possibly because the frequency of contacts between Personal Adviser and clients did not increase, and that for the 'hard to help' a more radical intervention was required (Hasluck, 2002).

More significant changes were introduced nationally in April 2001. The Government described these changes as a 'step change', with the programme 're-engineered' to make it more flexible and intensive. The 
New Deal for 25 Plus now more closely resembles the New Deal for Young People; the changes being based on lessons learnt from the latter and the November pilots. Compared to the previous national and pilot versions of the programme, more measures are available, and Personal Advisers work more intensively with participants to ensure that barriers to work are discussed adequately. Previously, claimants thought there had been an over-emphasis on getting 'any job' (Bivand, 2000). The intention was to tailor provision to participants' needs and for claimants to spend less time on the programme. Staff were very supportive of the change in the programme (Winterbotham et al., 2002).

This re-engineered programme comprises:

- A Gateway period lasting up to four months where participants meet weekly their Personal Adviser. Early on an Action Plan is produced that outlines the steps to be taken to get the claimant a job. Personal Advisers provide initial help to find unsubsidised employment, advice on the actions needed to find work (including screening for basic skills), access to independent careers advice, and when required access to specialist services on, for example, drug dependency, debt management, self-employment. After four weeks the option of subsidised employment is available to participants. Those without unsubsidised employment at the end of the Gateway are referred to the Intensive Activity Period (IAP).

- An IAP is a period full-time activity that provides individually tailored packages of support to meet the needs of clients and help them move 
into paid work. It lasts for 13 weeks, and can be extended for a further 13 weeks. This package is agreed between the Personal Adviser, the provider and the client. The package can include Basic Employability Training (BET) for up to six months to overcome barriers to work; support for self-employment; work experience placements; and education and training courses that last for up to one year and lead to a recognised vocational qualification. Ongoing job-search is also a key feature of every IAP.

- Follow-through - Participants without employment after the IAP return to Jobseeker's Allowance and continue to receive support from a Personal Adviser. This stage can last for six weeks, but can be extended to three months. Participants not securing employment become re-eligible for the programme after 18 months claiming Jobseeker's Allowance.

Initially, people aged 25 and over and who had been unemployed for 18 or more months were eligible for the re-engineered programme, this was later revised to unemployed for 18 out of the previous 21 months. The New Deal for 25 Plus is not the only provision available to those aged over 25 . At six months unemployment jobseekers can receive basic skills training (BET) and soft or key skills training (Soft Job Focused Training (SJFT)), at 12 months there is Longer Occupational Training (soft and key skills training of a longer duration than SJFT) and for the over 50 s there is New Deal 50 Plus. Those on the New Deal 25 Plus also have access to the New Deal for Musicians. 
In the 2002 Budget the Chancellor of the Exchequer announced two reforms to the New Deal 25 Plus, namely, that:

- pilots would be established to test extending on a mandatory basis the eligibility of jobseekers who had been unemployed for 18 months out of the previous three years (as opposed to 18 of the previous 21 months). This measure is designed to address those with repeat spells of unemployment, because they are at risk of long-term unemployment; and

- the introduction of a more intensive mandatory Gateway to work courses for all participants in four locations (Dundee, London, Manchester and Swansea). Mirroring the New Deal for Young People Gateway participants who have not found unsubsidised employment can be referred to courses to provide assistance on CV writing, jobsearch methods and interview techniques.

An objective of the April 2001 changes was to provide a service that was tailored to the needs of the customer. The programme did (eventually) deliver earlier interviews and more frequent contacts between Personal Advisers and clients, and a form of case conferencing where staff discussed individual cases. The latter was seen as a positive development by staff; although not fully implemented in all (case study) areas (Wilson, 2002). These measures serve to intensify participants' jobsearch activities and possibly the likelihood of them obtaining work. Qualitative research with staff suggests that the weekly interviewing 
regime during the Gateway improved their relationships with clients (Hasluck, 2002). The Gateway was seen as being effective for customers that were work ready; there were more mixed views on its benefits for "harder to help" participants (Wilson, 2002). Participants are reported as finding the revised Gateway a positive experience (compared to their usual experiences of the service) (Hasluck, 2002).

Claimants do discuss with providers and their Personal Advisers the nature of their IAP. However, the improvement in Personal Advisercustomer relations did not extend to the IAP. There were fewer contacts between Personal Advisers and participants during the IAP than originally envisaged, because Personal Advisers lacked the time and were reluctant to visit employers and training providers (Hasluck, 2002; Wilson, 2002). Possibly as a consequence of this, participants undertook less job-search activity during their IAP.

The extent to which the New Deal for 25 Plus delivers a flexible and personalised service appears to depend upon the skills of the Personal Adviser and the provider (Wilson, 2002). Whilst Jobcentre Plus is involved in the delivery of New Deal 25 Plus in all areas, much of the programme (including assistance with job-search) is provided by contractors. Early on there was some tension between Personal Advisers and training providers, arising from different interpretations about the extent to which New Deal for 25 Plus was focused on job outcomes, and lack of clarity about who had responsibility for deciding the provision for clients 
(Winterbotham et al., 2002). This tension appears to have diminished as Personal Advisers and providers have reached a common understanding on the primary purpose of the programme.

Case studies of the re-engineered programme demonstrate a wide variation in delivery of the programme (Wilson, 2002). The length and management of the Gateway and the type of provision can vary (Winterbotham et al., 2002). For most participants there is even access to the New Deal for Young People's Gateway to Work, courses that typically last two weeks and focus on soft skills and motivation. However, qualitative studies show that access to more services, such as drug counselling and financial advice, is more limited, because of its specialist nature or lack of provision (Hasluck, 2002). Similarly, there were differences in the local delivery of the IAP.

\section{Discussion and conclusion}

This chapter has sought to demonstrate that the welfare reforms introduced by Labour have become more personalised over time. Here 'personalisation' reflects the 'differentiation and flexibility of social life' and the 'rights and responsibilities' discourses outlined by Valkenburg in Chapter 1. The possible reasons for this increased individualisation are, first, lessons have been learnt from the operation of the New Deals that suggest that assisting claimants of non-Jobseeker's Allowance benefits into work requires a more personalised service than hitherto. These client groups are heterogeneous and addressing their barriers to work demands 
a flexible suite of measures, not a set menu where customers are effectively fitted to the provision available. Secondly, and a related point, the roll-out of Jobcentre Plus with mandatory 'work-focused interviews' for recipients of non-Jobseeker's Allowance benefits means that Advisers increasingly have to provide a service to a wider range of client groups. Thirdly, there is some evidence of policy learning in that lessons about what works in New Deal for Young People and New Deal 25 Plus have been transferred across the programmes. Fourthly, given falling, and low, levels of unemployment the mandatory New Deals are now increasingly focused on groups of people who are further away from the labour market and thus harder to reach. Arguably the Government's target of increasing the number in employment over the economic cycle requires that a more personalised service is provided as harder to reach groups are helped into jobs.

As well as the continuous development of the New Deals, the extension of a more flexible Personal Adviser model must be seen in the context of ongoing debates about the reform of the public sector. The championing of choice in service provision does seem to herald the next phase in the application of the 'new public sector school of management' to the U.K. The underlying reform discourse draws upon the marketisation of public services (c.f Chapter 1) and in particular the notion of consumer choice. However, the application of choice to employment and benefit services is problematic. For example, in the New Deal for Disabled People, which did seek to give participants a degree of choice in the provider they used, 
some participants were unaware that they had a choice (Stafford et al., 2004). Where participants did know they had a choice, often they selected a provider on grounds of their proximity and accessibility rather than on the basis of the service provided. Few participants in New Deal for Disabled People actively investigated what services different providers offered. Choice in activation services does require the delivery of informed choice.

Moreover, there are limits to the extent to which a national service covering a wide range of client groups can be 'personalised'. Issues such as 'high' staff turnover in Jobcentre Plus, lack of training in dealing with the hardest to reach, staff not being aware of the full range of provision within a locality and staff finding it difficult to engage in meaningful work-focused discussions with claimants of benefits other than Jobseeker's Allowance (especially those in receipt of incapacity benefits) will constrain the degree to which welfare to work services can be tailored to individual claimants.

Predicting the future direction of policy is a precarious activity and prone to error. Nevertheless, it is anticipated that the delivery of programmes will, whilst unemployment levels remain low, become more personalised in the UK.

\section{Acknowledgements}

Thanks are due to Sharon Walker and Nicola Selby at CRSP who helped to prepare the manuscript and Laura Adelman who produced Table 1. 


\section{References}

Arthur, S., Corden, A., Green A., Lewis, J., Loumidis, J., Sainsbury, R., Stafford, B., Thornton, P. and Walker, R. (1999) New Deal for Disabled People: Early Implementation ${ }_{2}$ DSS Research Report 106, London: Corporate Document Services.

Atkinson, J. (1999) New Deal for Young Unemployed People: A summary of progress, Research and Development Report ESR13, Sheffield: Employment Service.

Berthoud, R. (2003) Multiple Disadvantage in Employment: A quantitative analysis, York: JRF/YPS.

Bivand, P. (2000) 'Re-Engineered New Deal for 25 Plus' Working Brief, 120 www.cesi.org.uk/_newsite2002/publications/wb/w120/html/newdeal25plus. htm. Download date 27 September 2002.

Blair, T. (2004) PM speech on reforming the Civil Service, 24 February 2004, www.number-10.gov.uk/output/Page5418.asp, Downloaded 29 February 2004.

Blunkett, D. (2000) 'On your side' The new welfare state as the engine of prosperity, London: DfEE. 
Bonjour, D., Dorsett, R., Knight, G., Lissenburgh, S., Mukherjee, A., Payne, J., Range, M., Urwin, P. and White, M. (2001) New Deal for Young People: National Survey of Participants: Stage 2, Research and Development Report ESR67, Sheffield: Employment Service.

Bryson, A., Knight, G. and White, M. (2000) New Deal for Young People: National survey of participants: stage 1, Research and Development Report ESR44, Sheffield: Employment Service.

Chatrik, B. and Convery, P. (1999) The New Deal Handbook, London: Unemployment Unit and Youthaid.

Department for Work and Pensions (2005) The Department for Work and Pensions Departmental Report 2005, London: DWP.

Eagle, A. (1999) 'Implementing ONE: Government's expectations', Effectively Delivering Welfare to Work ONE - the single work-focused gateway, QMW Public Policy Seminars, 12 October.

Finch, H., O'Connor, W. with Millar, J., Hales, J., Shaw, A. and Roth, W. (1999) The New Deal for Lone Parents: Learning from the prototype areas, DSS Research Report No. 92, Leeds: CDS.

Griffiths, R., Irving, P. and McKenna, K. (2003) Synthesising the Evidence 
on Flexible Delivery, DWP Research Report No 171, Sheffield: DWP.

HC (1998a) New Ambitions for our Country: A new contract for welfare, Cm. 3805, London: TSO

HC (1998b) A new contract for welfare: The Gateway to Work, Cm. 4102, London: The Stationery Office.

HC (1999) Modernising Government, Cm. 4310, London: TSO.

HM Treasury (2000a) Budget 2000 Prudent for a Purpose: Working for a stronger and fairer Britain, HC 346, London: The Stationery Office.

HM Treasury (2000b) Spending review 2000 Prudent for a Purpose:

Building opportunity and security for all, London: The Stationery Office.

HM Treasury (2002a) Opportunity and Security for All: Investing in an enterprising, fairer Britain New Public Spending Plans 2003-2006, Cm 5570, London: The Stationery Office.

HM Treasury (2002b) Budget 2002 Financial Statement and Budget Report, www.hmtreasury.gov.UK/Budget/bud_bud02/budget_re../bud_bud02rechap4.cfm. Download date 24 April 2002. 
HM Treasury (2005) Britain meeting the global challenge: Enterprise, fairness and responsibility, Pre-budget Report December 2005, Cm 6701, London: The Stationery Office.

HM Treasury/DWP (2003) Full Employment in Every Region. London: The Stationery Office.

Hasluck, C. (2000) The New Deal for the Long Term Unemployed - A Summary of Progress, Research and Development Report No. ESR46, Sheffield: Employment Service.

Hasluck, C. (2002) The Re-Engineered New Deal 25 Plus: A summary of recent evaluation evidence, WAE Report 137, Sheffield: Department for Work and Pensions.

Finch, H., Of'Connor, W. with Millar, J., Hales, J., Shaw, A. and Roth, W. (1999) The New Deal for Lone Parents: Learning from the prototype areas, DSS Research Report No. 92, Leeds: CDS.

Kelleher, J., Youll, P., Nelson, A., Hadjivassiliou, K., Lyons, C. and Hills, J. (2002) Delivering a Work-focused Service Final findings from ONE case studies and staff research, DWP Research Report No. 166, Leeds: CDS.

Legard, R. and Ritchie, J. (1999) New Deal for Young Unemployed People: National Gateway, Research and Development Report ESR16, 
Sheffield: Employment Service.

Legard, R., Ritchie, J., Keegan, J. and Turner, R. (1998) New Deal for Young Unemployed People: The Gateway, Research and Development Report ESR8, Sheffield: Employment Service.

Lewis, J., Mitchell, L., Sanderson, T., Of'Connor, W. and Clayden, M. (2000) Lone Parents and Personal Advisers: Roles and Relationships, DSS Research Report No. 122, Leeds: CDS.

Loumidis, J., Stafford, B., Youngs, R., Green, A., Arthur, S., Legard, R., Lessof, C., Lewis, J., Walker, R., Corden, A., Sainsbury, R. and Thornton, P. (2001) New Deal for Disabled People: Evaluation of the Personal Adviser Service. London: Corporate Document Services.

Millar, J. (2000) Keeping Track of Welfare Reform: The New Deal Programmes, Paper presented to JRF Seminar on Work, Security and the Single Gateway, 15 March, London.

National Statistics (2005) Labour Market Statistics November 2005, London: National Statistics.

Osgood, J., Stone, V. and Thomas, A. (2002) Delivering a Work-focused Service: Views and experience of clients, DWP Research Report No. 167, Leeds: CDS. 
Secretary of State (1997) 'Harriet Harmon sets out plans to transform delivery of social security', DSS Press Release, 22 July.

Stafford, B. (2003a) 'Beyond lone parents: extending welfare to work to disabled people and the young unemployed', in Walker, R. and Wiseman, M. (eds.) The Welfare We Want? The British challenge for American reform, Bristol: The Policy Press.

Stafford, B. (2003b) 'Service delivery and the user', in Millar, J. (ed.) Understanding Social Security: Issues for policy and practice, Bristol: The Policy Press.

Stafford, B with Ashworth, K., Davis, A., Hartfree, Y., Hill, K., Kellard, K., Legge, K., McDonald, S., Reyes De-Beaman, S., Aston, J., Atkinson, J., Davis, S., Evans, C., Lewis, J., O’Regan, J., Harries, T., Kazimirski, A., Pires, C., Shaw, A. and Woodward, C. (2004) New Deal for Disabled People (NDDP): First synthesis report, DWP Research Report WAE199, Sheffield: DWP.

Vincent, J., Walker, R., Dobson, B., Stafford, B., Barnes, M. and Bottomley, D. (1998) Lone Parent Caseworker Pilots Evaluation Final Report, Centre for Research in Social Policy Working Paper 263, Loughborough: CRSP. 
Wilson, P. (2002) Evaluation of Re-Engineered New Deal 25 Plus, WAE Report No. 111, Sheffield: DWP.

Winterbotham, M., Adams, L. and Kuechel, A. (2002) Evaluation of New Deal for 25 Plus: Qualitative Interviews with ES staff, providers, employers and clients, WAE Report No. 127, Sheffield: DWP. 
1 In this paper the provision of 'personalised' services is taken to be synonymous with 'individualised' services, in the sense that services are seen as being tailored to meet the needs of individuals (see Chapter 1). However, more recent debates about the reform of public services in the U.K. have seen the emergence of a wider definition of 'personalised' services, which incorporate the notions of user involvement and co-production. As yet this wider definition has not been applied to employment and benefit services.

International Labour Office (ILO) definition of unemployment covers people who are: out of work, want a job, have actively sought work in the previous four weeks and are available to start work within the next fortnight; or out of work and have accepted a job that they are waiting to start in the next fortnight.

${ }_{3}$ At that time Jobcentre Plus was referred to as the Single Work-Focused Gateway, which was piloted as ONE, before being rolled out nationally as Jobcentre Plus. 